\title{
"A Nest to the Wandering Bird": Iowa and the Creation of American Judaism, 1855-1877
}

\author{
SHARI RABIN
}

THE FIRST JEW, and also the first naturalized foreigner, in the state of Iowa was Alexander Levi, a Frenchman who settled in Dubuque in 1833, five years before Iowa became a U.S. territory and 13 years before it achieved statehood. ${ }^{1}$ In the decades that followed, the state's Jewish population remained small but gradually increased, spreading to at least 35 different towns and cities (see map). ${ }^{2}$ Lone Jews could be found in Lime Springs, Atlantic, and elsewhere, while small clusters of Jews settled in places like Burlington, Ottumwa, and Muscatine, where they worked as peddlers and as merchants, especially in the clothing business. ${ }^{3}$

1. Oscar Fleishaker, "The Illinois-Iowa Jewish Community on the Banks of the Mississippi River" (Ph.D. diss., Yeshiva University, 1957), 7-8.

2. The population was an estimated 16 by 1846 and about 500 by 1860 . Michael J. Bell, "'True Israelites of America': The Story of the Jews of Iowa," Annals of Iowa 53 (1994), 88-89. The count of towns and cities is based on my survey of American Jewish newspapers. Using local newspapers, histories, and firsthand accounts, Simon Glazer comes to the same number. Simon Glazer, The Jews of Iowa: A Complete History and Accurate Account of Their Religious, Social, Economical and Educational Progress in This State; a History of the Jews of Europe, North and South America in Modern Times, and a Brief History of Iowa (Des Moines, 1904), 208.

3. See, for example, Jewish Messenger, 10/13/1876, 5; Israelite, 3/23/1855, 296; 2/22/1856, 269; American Israelite, 10/12/1875, 5; 12/7/1877, 6; Glazer, The Jews of Iowa, 203-7. Effective July 3, 1874, the Israelite changed its name to the American Israelite.

THE ANNALS OF IOWA 73 (Spring 2014). C The State Historical Society of Iowa, 2014. 


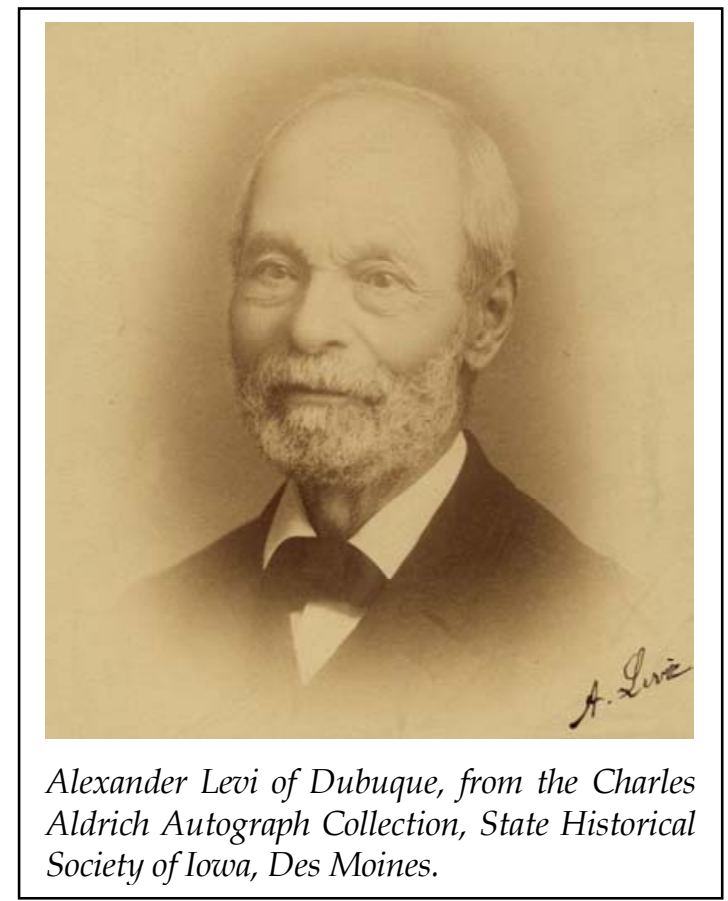

By the 1850s enough Jews had gathered in Dubuque and in the major Mississippi river towns of Keokuk and Davenport to organize Jewish communal life in the state for the first time. These Jews banded together for social and intellectual communion, Sabbath and holiday celebrations, and, as Keokuk Jews wrote in 1855, "for the purpose of purchasing ground for a burying place, assisting of the sick and arranging for meeting for synagogue purposes." 4 Jewish literary societies and fraternal lodges were organized in various communities, and the first congregation was founded in Keokuk in 1855, followed by Burlington (1856), Iowa City (1859), Davenport (1862), Dubuque (1863), and Des Moines (1873). ${ }^{5}$ The founding period of Jewish

4. Israelite, 8/24/1855, 54; 5/18/1855, 358; 9/28/1855, 90.

5. On fraternal orders and literary societies, see Occident 14 (1856), 504; Israelite, 6/26/1856, 2; Jewish Messenger, 8/5/1859, 36; Occident, July 1863, 43; Israelite, 1/17/1862, 230; 9/12/1873, 6; 7/26/1872, 11; Jewish Messenger, 7/17/1874, 2; American Israelite, 12/10/1875, 10. For congregations, see Israelite, 5/18/1855, 358; 2/22/1856, 269; 10/14/1859, 119; Occident 19 (1862), 522-23; Jewish Messen- 
MAP

LOCATIONS OF JEWS IN IOWA, 1855-1877

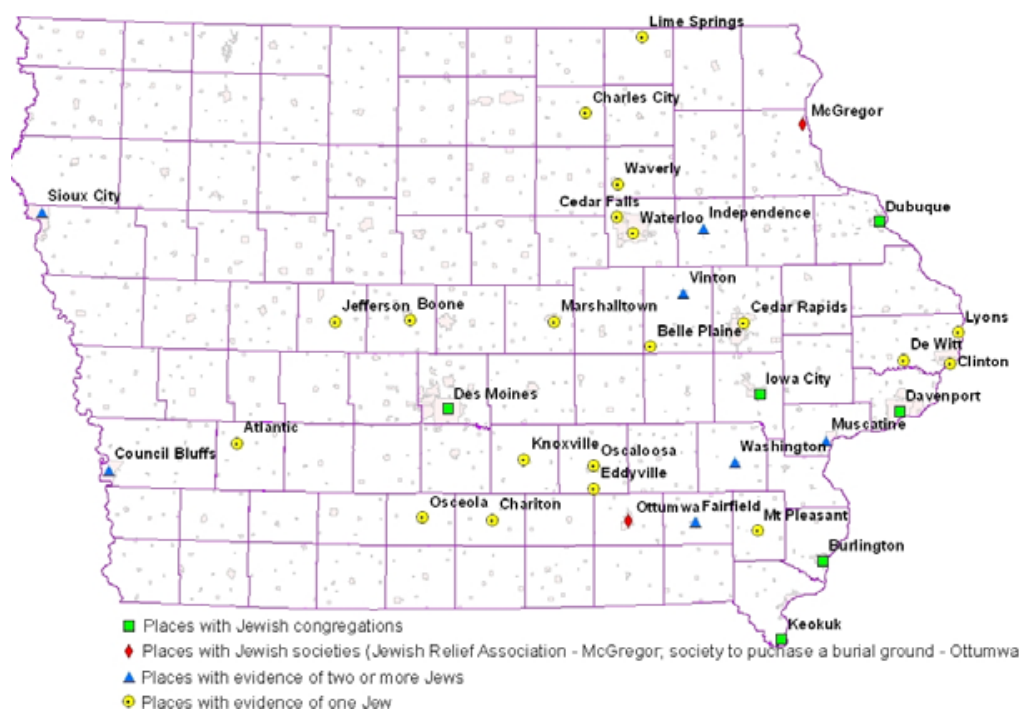

life in Iowa came to a close in 1877 with the dedication of the first synagogue building in the state in Keokuk. ${ }^{6}$

Iowa Jews were part of a mass migration that brought some 250,000 European Jews into the United States between 1820 and 1877.7 Whereas previously America's small Jewish population had resided predominantly in port cities on the eastern seaboard, now they went west with the expanding nation. ${ }^{8}$ Many Jewish men were peddlers who moved through the hinterland for their livelihood, and many relocated repeatedly in search of

ger, 7/10/1863, 13; Israelite, 11/14/1873, 6. The Jews of McGregor organized a "Jewish Relief Association" in 1865, and the Jews in Ottumwa organized to purchase a burial ground in 1875 . Israelite, 3/17/1865, 301; 10/12/1875, 5.

6. American Israelite, 8/3/1877, 4.

7. Leon A. Jick, The Americanization of the Synagogue, 1820-1870 (Hanover, NH, 1976), 26, 17-18; Isaac Mayer Wise, The Western Journal of Isaac Mayer Wise, 1877 (Berkeley, CA, 1974), 4; Jonathan D. Sarna, American Judaism: A History (New Haven, CT, 2004), 63.

8. Jonathan Sarna, "Port Jews in the Atlantic: Further Thoughts," Jewish History 20 (2006), 213-19. 
a better economic situation. ${ }^{9}$ Composed early on of such ambitious and mobile young men, some congregations-including those in Keokuk, Davenport, and Dubuque, for instance-were founded, went defunct, and then were reestablished. Even more permanent institutions faced considerable challenges, however. ${ }^{10}$

The small number of Jews made it challenging to procure the quorum of ten Jewish men required for prayer, and the limited resources and religious skills of migrants hindered adherence to the ancient Jewish legal codes governing details of time, food, and bodies. In Europe, where Jews were restricted in residence and travel, these functions of Jewish life had been organized through local government-supported communal bodies. In England and France, Jewish communal life was also organized on larger national and regional scales, but in German lands, where most Jewish immigrants came from, local institutions, or gemeinde, within specific towns and cities were the exclusive medium of Jewish interaction and identification.

These communal structures, served by governmentappointed rabbis, regularized the relationship between Jews and the state and formalized community on a local scale. Even with the rise of the controversial Reform movement, which sought to harmonize Judaism with Enlightenment ideas, the vast majority of institutional communities contained all Jews in one place within a single social body, no matter their varying proclivities and pieties. This ensured consistency and integrity of religious practice, which was based in part on minhag, or rite, which allowed for diversity in liturgy and practice between, for example, Germany and Poland. ${ }^{11}$ In the United States, however,

9. Louis C. Hunter, Steamboats on the Western Rivers: An Economic and Technological History (Cambridge, MA, 1949); Hasia R. Diner, A Time for Gathering: The Second Migration, 1820-1880 (Baltimore, 1992), 62.

10. Israelite, 3/28/1856, 307; American Israelite, 7/10/1874, 5; Glazer, The Jews of Iowa, 221; Jack Seymour Wolfe, A Century with Iowa Jewry: As Complete a History as Could Be Obtained of Iowa Jewry from 1833 through 1940 (Des Moines, 1941), 239.

11. R. Liberles, "Emancipation and the Structure of the Jewish Community in the Nineteenth Century," The Leo Baeck Institute Yearbook 31, no. 1 (1986), 51-67; Jay R. Berkovitz, The Shaping of Jewish Identity in Nineteenth-Century France (Detroit, 1989); Michael A. Meyer, Response to Modernity: A History of the Reform Movement in Judaism (Detroit, 1995); J. J. Petuchowski, "Abraham Geiger and Samuel Holdheim: Their Differences in Germany and Repercussions in America," The Leo Baeck Institute Yearbook 22, no. 1 (1977), 139-59. 
Jews from all over Europe with a variety of traditions could and did move as relatively unencumbered individuals throughout a vast continent. As they did, they found few Jewish institutions and no official means of identifying, let alone compelling, group membership or personal observance apart from voluntary affiliation.

In the small, independent communities that Jews created, it was an achievement when, for example, during the autumn high holidays of 1862, members of the Iowa City congregation "suspended our business the past Rosch Hashona [New Year's] and celebrated the day in its usual custom and shall do the same on the coming Day of Atonement."12 Likewise, it was notable that the young men of Davenport managed to procure a Torah scroll and two high holiday prayer books from New York in 1857 and that Dubuque had a shochet, or kosher butcher, as early as 1863.13 There were occasional traditionalists, such as Rabbi Joshua Falk Cohen, a distinguished Hebrew scholar who lived briefly with his family in Keokuk before his death in 1865, but punctilious observance was the exception. ${ }^{14}$ Ambitious young men far from Jewish resources and authorities often put business ahead of religious life. In 1875 in Keokuk-arguably the most established congregation in Iowa - ten women were allowed to count as a prayer quorum on Sabbath mornings instead of the traditional ten men because, in the words of one member, "Many a time we could not open at all if we had to wait for our men, who always make the well-known excuse: 'We like to come, but we can not lose the best business day in the week.'"15

Some communities were able to hire hazanim - non-rabbinic religious functionaries - to teach, perform ritual tasks, and lead services. In 1862 Davenport Jews briefly employed the first Jewish religious leader in Iowa, Henry Loewenthal, most recently

12. Israelite, 10/10/1862, 106.

13. Israelite, 8/28/1857, 62; Occident, July 1863, 43.

14. Occident, February $1865,47$.

15. American Israelite, 11/19/1875, 5. The nineteenth-century American work week was six days, and in many places laws prohibited work on Sunday. Alexis McCrossen, Holy Day, Holiday: The American Sunday (Ithaca, NY, 2001). 
of Buffalo, New York, who soon opened a school and began directing a small choir. In the 1870s he was succeeded by the Rev. Mr. Fall. ${ }^{16}$ Dubuque hired Rev. A. Alexander as teacher and minister in 1863 and Rev. L. Schlessinger in 1867.17 In the late 1860s and early 1870s Keokuk was served by a string of men, including Revs. Schwed, I. M. Sugenheimer, M. Strauss, and Ferdinand Becker. ${ }^{18}$ The turnover in these jobs indicates the difficulty of finding and retaining religious leaders in Iowa, especially since few congregations had the means to provide for candidates' traveling expenses. ${ }^{19}$

Although there were few religious functionaries in America, independent-minded Jews could hire and fire at will-and did so regularly. In the 1860s Rev. Loewenthal of Davenport complained that local Jews did not seem to want a religious leader at all. His congregants were, he wrote, "sweetly hoping to return to their former comforts of no Teacher, no Shochet, no Hazan and no Mohel [ritual circumcisor] and above all no need of going to the house of prayer every Sabbath." 20

If congregants could choose to hire whomever they wanted, or no one at all, qualified individuals could also choose to refuse to help. In 1862 a man in Iowa City who had the skills to lead services pompously gave himself the title of rabbi, but also went hunting and riding on the Sabbath and refused to lead high holiday services. ${ }^{21}$ With the constant relocation and lack of regulation of religious leaders, it was also difficult to know whom exactly a congregation was hiring. Keokuk correspondent Cassi Sembach complained in 1871 that applicants to serve small-town congregations were, "with a few exceptions, persons of low moral character, or possessing no merit for the position they are to fill." 22

16. Jewish Messenger, 4/11/1862, 113; Israelite, 9/12/1873, 6.

17. Occident, July $1863,43$.

18. Israelite, 8/26/1870, 11;8/11/1871, 7; 1/17/1873, 7; American Israelite 7/10/ 1874,5 .

19. Israelite, $7 / 1 / 1870,11$.

20. Israelite, $7 / 11 / 1862,10$.

21. Israelite, 10/10/1862, 106.

22. Israelite, $8 / 4 / 1871,6$. 
Such reports appeared in the nascent American Jewish press, which played a central role in local Jewish life. Jews throughout the state of Iowa subscribed to Jewish publications; used them to seek information, advice, and religious leaders; and wrote to them describing their communities and experiences. ${ }^{23}$ In the absence of established religion and accessible resources, Jewish newspapers became the central means of creating and disseminating authority, information, and community, in the process shaping local Jewish life and creating a national American Jewry.

In documenting the American Jewish experience, historians have produced many valuable regional and local studies, which only secondarily address larger stories of national institutions and intellectual trends. While these local studies have a tendency to present their subjects as inherently coherent, independent, and distinct, national studies either sidestep issues of geography or focus on New York and other large cities, using demographic measures and communal persistence into the twentieth century as measures of significance, thus marginalizing Jewish communities in places like Iowa. ${ }^{24}$ Using the press not just as a sup-

\section{Occident 19 (1861), 522-23; Occident, April 1862, 3.}

24. The ur-history of Iowa Jews is Simon Glazer, The Jews of Iowa. Rabbi Glazer's 1904 work set the template for later studies in gathering information from local newspapers and directories as well as from the reminiscences of Iowa Jews, with relatively little attention to the American Jewish press. While helpful in providing data about Iowa Jews historically and contemporaneously, such studies, most of which were written by local leaders for communal anniversaries, tend toward grandiose celebrations of Jews in Iowa and lachrymose laments of their demographic decline. See also Wolfe, A Century with Iowa Jewry; Frank Rosenthal, The Jews of Des Moines: The First Century (Des Moines, 1957); Fleishaker, "The Illinois-Iowa Jewish Community"; Bernard Shuman, A History of the Sioux City Jewish Community, 1869 to 1969 (Sioux City, 1969); and Bell, "True Israelites of America." For other local studies, see also, for example, Steven Hertzberg, Strangers within the Gate City: The Jews of Atlanta, 1845-1915 (Philadelphia, 1978); Ellen Eisenberg, Ava F. Cahn, and William Toll, Jews of the Pacific Coast: Reinventing Community on America's Edge (Seattle, 2009). For the emphasis on urbanism, especially New York, in American Jewish history, see Hasia Diner, The Jews of the United States, 1654-2000 (Berkeley and Los Angeles, 2006); and idem, A Time for Gathering. Deborah Dash Moore, At Home in America: Second Generation New York Jews (New York, 1983), 4, has argued that "New York Jews devised the grammar of American Jewish life." On debates about the significance of region and for an argument that small towns significantly shaped Jewish life in a later period, see Lee Shai Weissbach, Jewish Life in Small-Town America: A History (New Haven, CT, 2005), 8. Whether or not Jewish life has been decisively shaped by particular places, states, or re- 
plementary source but as a central tool for understanding the formation of identity and community shows that the relationship between local Jewish communities and national ideas and institutions has in fact always been fully interdependent and mutually constitutive. ${ }^{25}$

That was especially the case in the nineteenth century, when American Judaism was just coming into being as a lived practice, a meaningful community, and a conceptual category. Local communities were deeply enmeshed in larger networks of interaction, and Jewish communities in places like Iowa, although demographically small, were central to larger considerations about the scope of Jewish community and the meaning of America for Jewish life. A growing Jewish population distant from the urban centers of American Jewish life, Iowa Jews were enthusiastic newspaper correspondents and frequent objects of curiosity to other American Jews and so are a particularly fruitful case study of the mutual interactions and collaborations that created local communities and what came to be understood as a national American Judaism.

THE AMERICAN JEWISH PRESS dates to 1843, when traditionalist Isaac Leeser began publishing the monthly Occident and American Jewish Advocate in Philadelphia. It was joined in 1854 by the weekly Israelite, edited by reformer Rabbi Isaac Mayer Wise of Cincinnati, and in 1857 by New York's weekly Jewish

gions, scholars would do well to note the ways in which our historical subjects perceived such differences and incorporated them into their self-conceptions and actions. Larger studies of nineteenth-century American Judaism have talked about various places but without investigating the centrality of mobility and geographic considerations to the formation of Jewish community and thought. Diner, The Jews of the United States; Sarna, American Judaism; Lance J. Sussman, Isaac Leeser and the Making of American Judaism (Detroit, 1996); S. D. Temkin, Isaac Mayer Wise: Shaping American Judaism (New York, 1992); Jick, The Americanization of the Synagogue.

25. James W. Carey, Communication as Culture: Essays on Media and Society (New York, 2009); Benedict Anderson, Imagined Communities: Reflections on the Origin and Spread of Nationalism (New York, 1998). On the role of the American Jewish press in spreading information in this period, see Diner, A Time for Gathering, 207. For a transatlantic perspective on the Jewish press in this period, see Adam Mendelsohn, "Tongue Ties: Religion, Culture and Commerce in the Making of the Anglophone Jewish Diaspora, 1840-1870" (Ph.D. diss., Brandeis University, 2008), 197. 
Messenger, founded by Rabbi Samuel Myer Isaacs. As early as November 1854, four months after its inauguration, the Israelite found an Iowa subscriber in Herman Miller of Keokuk. In the next year alone it would add subscribers in Davenport, Muscatine, and Vinton. ${ }^{26}$ By far the most popular of the papers, the Israelite at least once actively sought out Iowa subscriptions; in 1868 it sent a traveling agent through southern Iowa and elsewhere in the Midwest. ${ }^{27}$ The Occident's first subscriber in the state was David Kahn of Cedar Rapids. It gradually expanded its reach to Independence, Beloit, Dubuque, Cedar Falls, Davenport, and Muscatine. ${ }^{28}$ By 1875, "A. T." of Ottumwa could confirm that the Israelite "has made its appearance here, and I will guarantee a circulation of the paper, which it surely merits." That same year "Esox" of Burlington reported, "There are beside your humble correspondent a number of subscribers to your paper living here." A Lime Springs Jew reported to the Jewish Messenger in 1876, "We read the Messenger and lend it to one family here to read, and after they read it we get it and send it to a friend in Vermont." 29 Throughout the state and the nation, Jewish newspapers were familiar and welcome visitors.

The content of these papers was eclectic, including editorials, sermons, literary pieces, travel accounts, and advertisements as well as international and domestic news. Individual Jews wrote in to document marriages and deaths or simply to correspond with editors. In addition, the papers published reports from local communities. ${ }^{30}$ In 1856, having heard of the creation of a Jewish literary society in Davenport, Iowa, Isaac Leeser wrote in the Occident, "Would Mr. [Benjamin] Eiseman, the Secretary, have the kindness to inform us with regard to the number of Israelites in his city, the state of the congregation, and the names

26. Israelite, 11/17/1854, 152; 2/16/1855, 256; 3/23/1855, 296; 11/30/1855, 175; 12/14/1855, 191.

27. Israelite, $12 / 11 / 1868,4$.

28. Occident, October 1856, 2; March 1858, 2, April 1862, 2; April 1863, 2; July 1863, 2; May 1864, 2. I was not able to obtain Jewish Messenger subscription data about Iowa.

29. American Israelite, 10/12/1875, 5; 10/22/1875, 2; Jewish Messenger, 10/13/ 1876,5 .

30. See, for example, Jewish Messenger, 4/24/1874, 6; American Israelite, 10/22/ 1875,7 . 
of its officers and also those of his society? ... We should also be happy to obtain authentic information respecting other settlements of Israelites through Iowa, where we believe they are numerous in many towns." Eiseman replied in the next number, reporting that there was not yet a congregation in Davenport, which he blamed on recalcitrant married men, but that "regarding different congregations in Iowa ... there are at present, as far as my knowledge reaches, a congregation each in Dubuque, in Burlington and Keokuk, all in Iowa." 31

Leeser was not the only Jewish editor interested in learning about Jewish affairs in the state. In 1859 the Jewish Messenger reported of Iowa City, "A congregation has been established at this flourishing place. We have not learned particulars, but shall be happy to insert any information communicated to us on the subject." Local Jews happily obliged, expressing the pleasure and honor they took in their correspondence. "A Looker On," who wrote from Iowa City to the Israelite in 1862, considered it a "privilege" to "publish a few lines in your valuable sheet concerning Judaism in this part of the West." In 1869 "Reader" wrote to the Israelite from Keokuk, "Although having been a regular reader of yours since your journal made its first appearance, I never yet undertook to address you until now, hoping you will not refuse to hear even from this little place." In 1875 "Esox" of Burlington reported, "Though our place is well enough known in the mercantile world, yet you and many of your readers have probably never heard of it in regard to Jewish affairs. . . But permit me first a little space for picturing to you our place." After outlining the rapid development of the city itself, he described the Jewish community and its institutions, reporting, "There live in the city about twenty-five [Jewish] families, and they are all in well-to-do circumstances." 32

In such reports, correspondents included the people in their communities, the state of Jewish affairs, and the particularities of

\section{Occident 14 (1856), 504, 550-51.}

32. Jewish Messenger, 8/5/1859, 36; Israelite, 10/10/1862, 106; 1/15/1869, 2; American Israelite, 10/22/1875, 2. A. T. of Ottumwa wrote in 1875 , "It is indeed a refreshing privilege to have occasion to let you hear something from these quarters and to publicly accord to the Israelites of this town credit for the inauguration and successful efforts accomplished." American Israelite, 10/12/1875, 5. 
their towns. In September 1855 the Jews of Davenport provided the details that they had "bought a parcel of land for $\$ 200$ to be used as a burial ground ... appointed a Shochet [butcher] and intend to organize a congregation, counting already about thirty families." In June of the following year Jews of Burlington wrote of their new congregation, B'nai Sholom, "At present it consists of 23 members," adding, "Mr. Jacob Shroder is President; Joseph Lehman, Treasurer; M. A. Newmark, Secretary." 33

News, for these Iowa Jews, was not the idle sharing of information but was part of a deeper impulse to claim space and assert their presence within the emerging social geography of the American Jewish press. So enthusiastically and with such detail did Iowa Jews correspond that it was almost as if a place did not exist if it was not reported in the Jewish press. In 1874 Cassi Sembach of Keokuk, noting that "it has been a very long time indeed since anything from this section of Iowa has appeared in the Israelite," wrote in "to show that we are not dormant." 34

Iowa Jews were also known about and imagined from afar through travel reports by Jewish leaders, namely Wise and his friend and colleague Rabbi Max Lilienthal. In 1856 Wise traveled up the Mississippi River to Iowa as part of a larger western tour. He described the prosperous situation of Keokuk and detailed how the local Jews had "formed a congregation, bought a lot of ground for a burial place, and attempt to build up a flourishing congregation." In Davenport and Rock Island, Illinois, he found 40 men in possession of a burial ground and a shochet, but also local rivalry across the state border, as "each place wanted the temporal synagogue located at its very door." Rock Island Jews had taken the first steps, and he was sure that soon "the best number of our friends in Davenport will join them." 35 Twenty-one years later Lilienthal went to Keokuk to consecrate the new synagogue. He admired the city itself, praised the activ-

33. Israelite, $9 / 28 / 1855,90 ; 6 / 26 / 1856,2$.

34. American Israelite, $7 / 10 / 1874,5$. The press served not only what theorist James W. Carey calls a "transmission" role, relaying information and arguments, but also a "ritual" role, projecting communal ideals, encouraging fellowship and participation, and engaging in the creation and maintenance of an American Jewish world. Carey, Communication as Culture.

35. Israelite, 8/1/1856, 29. 
ities of the local Jewish ladies, and then provided a history of the congregation. ${ }^{36}$ Lilienthal and Wise's travel reports, like the correspondence of local Jews, shared information and gave far-flung Jews a glimpse into the lives of their coreligionists elsewhere.

If Jews in different places came to know about and identify with one other through the circulation of information, they further expressed and fostered translocal identities through the circulation of money. As the nation's primary Jewish institution, the press played an important role in coordinating and advertising charitable efforts for Jews in various places. While Iowa Jews offered philanthropic aid to their coreligionists in Europe and the Holy Land, thus identifying as part of the global Jewish people, beginning in the 1860s and 1870s, they increasingly supported and identified with their coreligionists elsewhere in the nation. ${ }^{37}$ During the Passover holiday of 1867 and 1868, Abraham Greenewald of Dubuque donated 238 pounds of meat to Chicago's United Hebrew Relief Association, and the Jews of Davenport donated $\$ 51$ "in Behalf of the Suffering Israelites in New Orleans" during the 1867 yellow fever epidemic. ${ }^{38}$

Iowa Jews were also very active in B'nai B'rith, the national Jewish fraternal order, and supported its orphan asylum in Cleveland, the only such institution for Jewish youth in the country. ${ }^{39}$ Moses Bloom, a successful clothing merchant soon to be elected mayor of Iowa City, had been an Israelite subscriber

36. American Israelite, 8/3/1877, 4; 8/10/1877, 5.

37. On Iowa Jews' international connections and philanthropy, see Jewish Messenger, 12/1/1865, 165; Fleishaker, "The Illinois-Iowa Jewish Community," 66; Jewish Messenger, 12/14/1877; Israelite, 5/10/1867, 3; 3/19/1869, 6; 2/26/1869, 6; Jewish Messenger, 5/31/1872, 3; Israelite, 8/16/1872, 10.

38. Occident, June 1867, 32; Jewish Messenger, 11/8/1867, 2.

39. B'nai B'rith also contributed to the development of local Jewish life and a sense of national communality. See Cornelia Wilhelm, The Independent Orders of B'nai B'rith and True Sisters: Pioneers of a New Jewish Identity, 1843-1914 (Detroit, 2011); and Deborah Dash Moore, B'nai B'rith and the Challenge of Ethnic Leadership (Albany, NY, 1981). By 1873 there were B'nai B'rith lodges in McGregor, Davenport, and Keokuk, and in 1875 Burlington founded one. Israelite, 3/21/1873, 5; American Israelite, 12/10/1875, 5. Among those who attended the Benai Berith Convention in Chicago the next year were A. Kohn from McGregor and S. Klein of Keokuk. Jewish Messenger, 1/23/1874, 5. B'nai B'rith District Grand President Henry Ullman visited Keokuk in 1877. American Israelite, 7/20/1877, 2. 


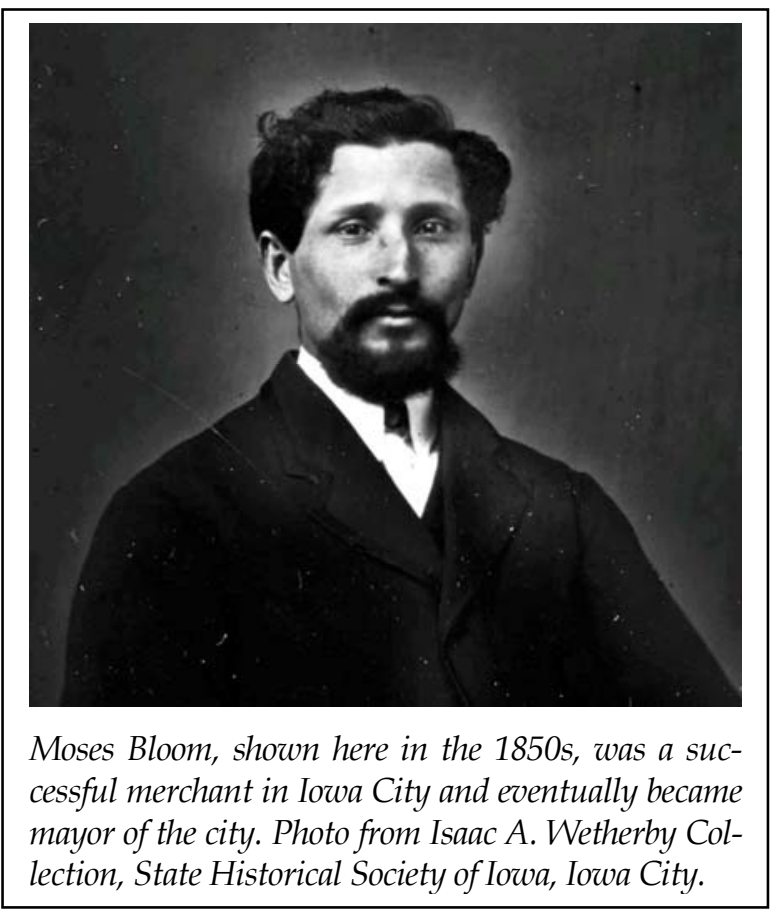

since 1862; in 1871 he donated $\$ 300$ to the asylum in memory of his wife, Rosa. The donation was made on the condition that "a prayer be offered by the orphans every year on the anniversary of her death," a Jewish tradition requiring a quorum of ten Jewish men over age 13, which was hard to come by in Iowa City. 40 Seventeen individuals from McGregor made more modest gifts to the asylum in 1872, ranging from $\$ 1$ to $\$ 5$, and in 1877 more than a dozen individuals from Keokuk, half of them women, donated $\$ 2$ each. 41

The assistance flowed both ways. It was commonly assumed that Jews could rely on their coreligionists in other cities for aid, so when the Jews of Keokuk sought to build a synagogue in the 1870s, local correspondent Cassi Sembach wrote, "As our congre-

40. Israelite, $4 / 18 / 1862,335 ; 2 / 10 / 1871,10$. Bloom was also elected to the state legislature in 1877. Glazer, The Jews of Iowa, 321-26.

41. Israelite, 4/12/1872, 7; American Israelite, 6/8/1877, 7. On the orphan asylum, see Gary Edward Polster, Inside Looking Out: The Cleveland Jewish Orphan Asylum, 1868-1924 (Kent, OH, 1990). 


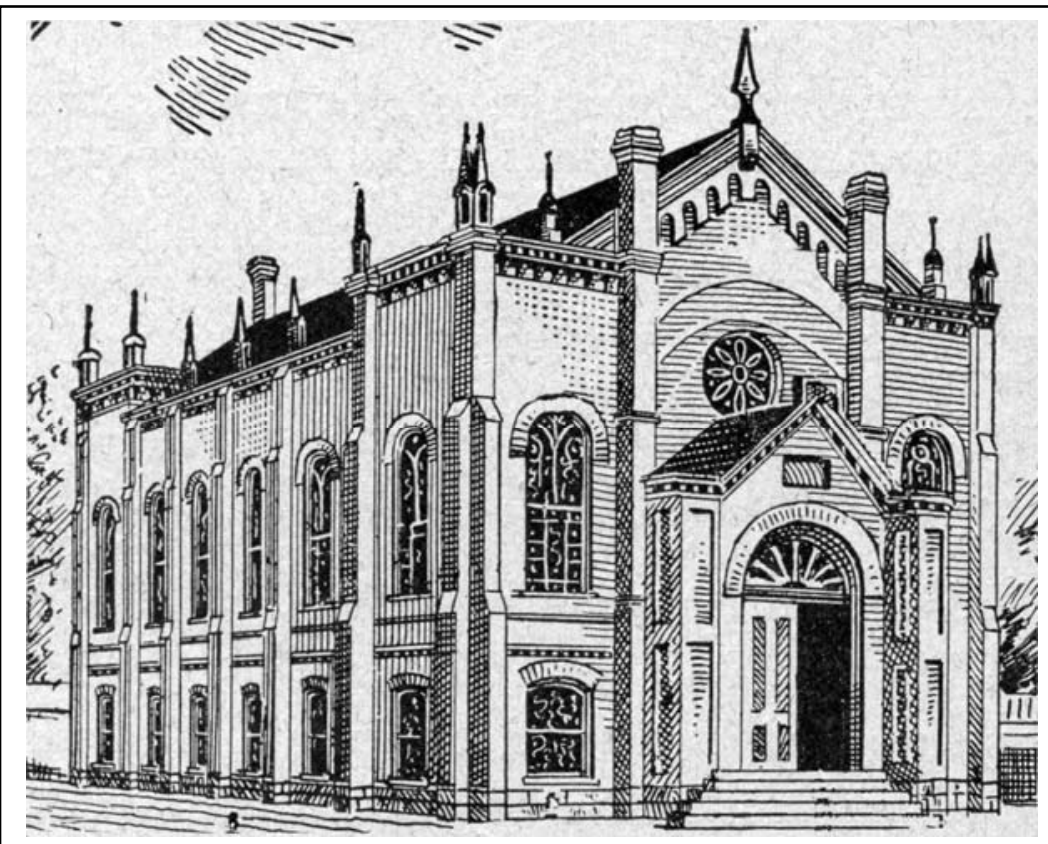

By 1877, Keokuk's Jews had raised enough money to complete the first synagogue building in the state, the B'nai Israel Temple. Sketch from Simon Glazer, The Jews of Iowa (Des Moines, 1904).

gation numbers less than twenty members, we will of necessity have to call for outside help." 42

In a highly mobile nation with Jews widely dispersed, the press became a crucial medium for circulating information and familiarity, serving both to link Jews and to represent their new settings to themselves and to others. ${ }^{43}$ Wise described travel reports as meant "for the instruction and amusement of our readers," but they were also intended, in the words of Leeser - who traveled considerably but never made it to Iowa-to "prompt

42. American Israelite, $7 / 10 / 1874,5$.

43. R. Glanz, "The Spread of Jewish Communities through America before the Civil War," YIVO Annual of Jewish Social Science 15 (1974), 15; idem, "Where the Jewish Press Was Distributed in Pre-Civil War America," Western States Jewish Historical Quarterly 5 (1972), 1-14. Wise repeatedly argued that the Israelite had "at least double the number of readers that we have subscribers" or "five times the number of its actual subscribers." Israelite, 7/11/1856, 4; 8/1/1856, 28. 
good-will and unity among all Israelites" by "furnish[ing] a connecting link to distant congregations [and] by informing them of the passing events in which all are interested." 44 These "connecting links," which were also created through local correspondence, helped fuel a national charitable economy in which Jews from different parts of the nation supported each other financially. Efforts to know and to help Jews in various places helped local communities conceive of themselves as part of an emerging if inchoate American Jewish network.

AS IOWA became a subject in the Jewish press and a part of an emerging national community, local correspondents and editors alike not only described the facts of Jewish life there, but also sought to understand its meaning. According to Nathan Hoffheimer, writing to the Israelite in December 1855, Keokuk's congregation gathered into the fold "many who have been wanderers in Israel and particularly estranged from the God of their fathers and from the hand that brought them out of the 'Land of Egypt,' and from the arm that saved them from the house of bondage." Here Egypt represented Europe, the wanderers were Jewish immigrants, and Keokuk was not only a bustling commercial river town but also a promised land in which Jews would return to their brethren and faith. The next year Benjamin Eiseman wrote of Davenport, "Where immigration finds its way, a part of Israel's children always follows. . . . The reason is, that our sacred cause is expounded everywhere and has its followers on the whole globe." Eiseman, like Hoffheimer, explained his Iowa town as one participant in the global project of Jewish history and community. 45

Tellingly, Keokuk's congregation was named the Benevolent Children of Jerusalem, and then Benai Israel (Children of

44. Occident 15 (1857), 3; 4 (1846), 5.

45. Israelite, 12/14/1855, 189; Occident 14 (1856), 550-51. Later Iowa Jewish historians would make similar arguments about the global meaning of Iowa Jewry's inevitable triumph. For instance, Simon Glazer wrote, in The Jews of Iowa, "The Jews have been makers of history wherever they have chanced to penetrate, and ... on their march to carry Jehovah's banner to its goal, they have distinguished themselves with such remarkable achievements that the history of the smallest group of them is instructive to the whole human race" (156). 
Israel), which was also the name of Davenport's congregation. ${ }^{46}$ The Dubuque and Des Moines congregations, founded in 1863 and 1873, respectively, were both called Bene Yeshurun, a variant form of the same name, which used the poetic biblical name for Israel. ${ }^{47}$ These biblical self-understandings expressed the desire of Iowa Jews to see their specific places as residing within the larger religious geography of traditional Judaism. Rabbi Wise, during his 1856 trip, wrote, "I have not the least doubt, Keokuk will be a considerable congregation in but a few years. ... Our brethren are faithful, attached sincerely to the faith of Israel, and work incessantly to build a nest to the wandering bird." 48 Drawing from Proverbs and Psalms, Wise compared Iowa Jews to wandering birds; they found in their new nation and state protection like that offered by the ancient Temple in Jerusalem.

If biblical metaphors helped situate Iowa Jewry within the expanse of Jewish experience, providentialism and ideas of progress were used to gloss over the difficulties of Jewish life. "Onward and forward is the watchword of Israel. . . . We are progressing slowly but surely," Benjamin Eiseman wrote of Davenport, adding optimistically, "We know no such word as fail, with the guidance from an All-wise Providence." Keokuk's congregation was, according to Hoffheimer, "imbued with the true spirit of progress. ... With the smiles of Providence we hope to have the most respectable congregation in point of members, as well as high morality, that will be in this great Des Moines Valley." Marveling at the beauty and industrial progress of the

46. Israelite, 5/18/1855, 358; 12/14/1855, 189; 1/17/1862, 230. B'nai, Bene, and Benai are all variant transliterations of the Hebrew for "Children of."

47. Israelite, 9/15/1865, 85; 11/14/1873, 6. The first Ashkenazi synagogue in New York, founded in 1825, was also called B'nai Jeshurun. Sarna, American Judaism, 56. Yeshurun and Jeschurun are alternate transliterations of the same Hebrew word. It is found four times in the Bible. Encyclopaedia Judaica, ed. Michael Berenbaum and Fred Skolnik, s.v. "Jeshurun," accessed 12/19/2013, http:/ / go.galegroup.com/ps/infomark.do?action=interpret\&eisbn=978002866 0974\&prodId=GVRL\&userGroupName=imcpl1111\&type=aboutBook\&version $=1.0 \&$ authCount $=1 \& \mathrm{u}=\mathrm{imcp} 11111$. The publication of modern orthodox German rabbi Samson Raphael Hirsch, founded in 1854, was also called Jeschurun. Nils Roemer, Jewish Scholarship and Culture in Nineteenth-Century Germany: Between History and Faith (Madison, WI, 2005), 53.

48. Israelite, 8/1/1856, 29 (drawing on Psalm 84:4). 
Midwest, Wise likewise affirmed his beliefs in the "progress of mankind" and in a "rational providence watching over the destinies of humanity." 49

Providence and progress were powerful concepts in nineteenth-century America, seen as mutually supportive and closely linked to Manifest Destiny, the belief in the inevitable westward expansion of the United States. Jews borrowed from these optimistic ideas, redeploying them in the name of Judaism. The implicit argument was that, like the nation itself, Jewish life in Iowa, the West, and throughout America would progress in piety and through space under benevolent providential guidance. Leeser summarized this view in 1859 when discussing the new congregation in Iowa City. "As civilization progresses in the West and erects its monuments, so Judaism progresses along side of its younger sister." 50 Those who appealed to this combination of providence and progress minimized the importance of individual action, confidently asserting that flourishing Jewish life was an inevitable outgrowth of the trajectory of Jewish and American history.

Even as they explained Iowa Jewish life within the framework of world Jewry, however, Iowa Jews continued to think of themselves, and to be thought of, as locally distinct. Distant Jewish leaders tended to think of Jews in the various Iowa cities and towns as one body within the state, although locals usually saw themselves instead as part of a specific town's community. When Leeser requested information about "settlements of Israelites through Iowa," Eiseman - whose community actually included Illinois Jews across the Mississippi River-knew enough to name the congregations but "the names of the officers I do not know." A rare exception was an 1856 letter written by the Jews of Burlington offering "our sincere thanks to the Rev. Dr. Wise not only in our name, but in the name of the Jews throughout the state of Iowa." On his trip to Keokuk to dedicate the congregation's new synagogue, Max Lilienthal discussed its place in relationship to other communities in the state. "There are other towns in Iowa in which our brethren dwell in larger

49. Occident 14 (1856), 550-51; Israelite, 12/14/ 1855, 189; 7/25/1856, 22. See also Israelite, 8/28/1857, 62.

50. Occident, 10/14/1859, 119. 
numbers and possessing more wealth than in Keokuk; but so far they have not organized for the purpose of erecting synagogues." Even as he singled out Keokuk for praise, Lilienthal continued to think about the state of Iowa as a meaningful geographic unit for understanding Jewish life. ${ }^{51}$

In the Jewish press, Iowa as a state was noted for its remarkable economic growth as well as its Sunday closing laws, which banned work during the Christian Sabbath and overwhelmingly affected Jews. In regard to religious life, Iowa was known for its ignorant local reporting on Jewish issues, active Jewish convert missionaries, and sectarianism in public life. ${ }^{52}$ Iowa was also mentioned in relationship to various schemes for Jewish agricultural colonies, which many believed would enable more stable economic and religious life. ${ }^{53}$ Understood as part of a state that epitomized American Protestant activism and rural life, Jewish communities within Iowa cities were used as powerful examples of persistent religious life in the face of difficult odds. As Leeser wrote of new congregations in the West in 1859, "Leavenworth City, St. Joseph, Weston and Iowa City are nearly at the edge of civilization and in all these places Judaism has root and branch." In 1863 he wrote of the new congregation in Dubuque, "It can easily be imagined that every member is taxed very much to keep up this new society; but we believe the sacrifices are cheerfully brought in the interest of religion." 54

The Jewish Messenger also praised the Jews of Dubuque for having "determined to establish regular public worship in accordance with the customs of their forefathers." "It is astonish-

51. Occident 14 (1856), 550-51; Israelite, 2/22/1856, 269; American Israelite 8/3/ 1877, 4. Jack Wolfe, A Century with Iowa Jewry, 55, claimed that peddlers' mobility, the rise of Jewish institutions in the state, and developments in transportation and communication made it so that "the Jews of this state [were] molded into one of the most closely integrated groups scattered over a wide area to be found anywhere in America. . . . The religion, culture, social life, and habits of the Jews of Iowa are amazingly uniform throughout the whole state." Whether this was true in the 1940s or not, it certainly was not in the mid-nineteenth century; his comments point to the persistence of the impulse to declare various geographic units as containing a coherent, unified Jewish community.

52. Occident 13 (1855), 558-61; Israelite, 8/14/1857, 46; 11/26/1858, 165; 12/3/ 1858, 174; 12/26/1873, 6; American Israelite, 5/26/1876, 6.

53. Israelite, 8/16/1872, 10; Jewish Messenger, 8/23/1872, 4.

54. Occident, 10/14/1859, 119; Occident, July 1863, 43. 
ing," the author continued, "how many congregations are constantly springing up in the West! ... We hail with pleasure each addition to the family of Jewish congregations." 55 The description of traditional and familiar Jewish life in Iowa seemed especially important and impressive to Leeser and others. This was their Jewish pastoral ideal: a pristine, empty landscape interrupted not only by industrial power but by the ancient religion of Israel. ${ }^{56}$ At a time when many wondered if Jewish life could survive in America at all, its remarkable institution in Iowa served as an example of right religious action that brought new places into an emerging "family of congregations" throughout the nation. ${ }^{57}$

In describing Iowa Jewish life, local Jews and editors alike invoked a complicated nexus of religious ideas to explain and argue for the compatibility of Judaism with life throughout America. They wanted to argue that locale mattered but also that Jews across the United States were part of one people and one religious practice that could thrive in any specific place. Biblical themes, providence, progress, and localism were invoked in reference to other communities, but the case of Iowa was particularly useful as a model of Jewish life persisting in unexpected places. Judaism in the state was cast as normalthe inevitable product of universal Jewish wandering and the workings of providential progress - but also as surprising and remarkable. It was proof that, in short, "Judaism holds equal step with civilization" and could flourish in any environment, be it city or country, north or south, east or west. ${ }^{58}$

THE LINKS created among American Jews and the ideas they developed about their localities fueled and were an expression of institutional plans for greater uniformity and cohesion among

55. Jewish Messenger, 7/10/1863, 13.

56. On the power of the pastoral ideal in nineteenth-century American culture, see Leo Marx, The Machine in the Garden: Technology and the Pastoral Ideal in America (New York, 2000).

57. Harvey Arnold Richman, "The Image of America in the European Hebrew Periodicals of the Nineteenth Century (until 1880)" (Ph.D. diss, University of Texas, 1971).

58. Israelite, $11 / 27 / 1863,173$. 
Jews throughout the United States. Wise's goal in the Israelite and on his 1856 midwestern voyage was "elevating Judaism, vis: education, union, and reform," specifically by establishing a college, a national institutional body, and a unified religious practice. ${ }^{59}$ Those were the main projects that he, Leeser, and others consistently advocated throughout the nineteenth century, seeking to tame unnerving congregational independence and diversity. It concerned them that the American continent was marked by "some two hundred Jewish congregations, scattered through the length and breadth of this land ... . absolutely distinct from one another in every respect." ${ }^{60}$ Drawing on the models of the American nation and Protestant denominations, they believed that this problem could best be solved through a national institutional "union" and a national religious practice, which would formalize existing networks of communication and travel while improving and standardizing religious life.

Beginning in the 1850s and 1860s, there were repeated efforts to establish a union and a college, which Iowa Jews enthusiastically supported. ${ }^{61}$ As early as 1855 Herman Friedlander, an active congregational leader in Dubuque, called a meeting in support of a Jewish college. That same year members of his community responded to an appeal in the Israelite, donating $\$ 32.50$ toward efforts to create Zion College, Wise's first attempted rabbinical seminary in Cincinnati. ${ }^{62}$ While such plans were advocated by multiple sources, among Jews in Iowa and throughout the nation those of Wise, who traveled extensively and whose newspaper was the most widely circulated, gained the most traction.

In 1856 Burlington Jews wrote an admiring letter to Wise, stating, "We, the Jewish citizens of Burlington, faithful to our

59. Israelite, 8/1/1856, 29.

60. Jewish Messenger, 2/8/1861, 42.

61. For an overview of these efforts, see Joseph Buchler, "The Struggle for Unity: Attempts at Union in American Jewish Life, 1654-1868," American Jewish Archives 2 (1949), 21-46, http:/ / americanjewisharchives.org/publications/journal/.

62. Israelite, $9 / 15 / 1865,85 ; 8 / 24 / 1855,54 ; 2 / 1 / 1856,243$. Wise went to great lengths to garner local support for the college, but then unilaterally established it in Cincinnati, alienating those same supporters. The school quietly closed around 1856 or 1857. Bertram Wallace Korn, Eventful Years and Experiences: Studies in Nineteenth-Century American Jewish History (Cincinnati, 1954), 156-59. 
religion, although few in number, and not yet bound into a congregation, have noticed for the last two years the exertions of the Rev. Dr. Wise in behalf of the welfare of the Jewish faith and zeal and sincerity to unite all our brethren in this country into One great congregation." The congregation praised Wise's activities, described him as a "champion," and wrote of its plans to send copies of its resolution to a range of American Jewish publications. Several community members subscribed to the Zion Collegiate Association and requested a printed prospectus with further information. Iowa Jews, familiar with the difficulties of hiring and retaining religious leadership and already linked through the Jewish press to a national community, rallied around the idea of translocal cooperation. ${ }^{63}$

Not only did Jewish leaders advocate the institutional union of American congregations, but Wise and other moderate reformers also insisted that Judaism "must be American in form, principle and spirit." 64 The multiple minhagim (rites) that immigrants had brought from Europe had to be eliminated in favor of a unifying rite and practice that was suitable to their new geographic context. Although they praised and affirmed local Jewish communities, Jewish leaders were troubled by religious eclecticism and diversity and believed that a unified religious practice would solve both problems. Wise, for one, worried that "in a course of twenty years we [will] not recognize each other any longer as Jews" because "not only each congregation, but each individual has his own and peculiar reforms." 65 A unified path of reform would prevent that calamity while making Judaism more suitable to American settings, including Iowa.

While Leeser and others hoped that earnest effort and the spread of information would enable the continuation of traditional Jewish practices without their alteration, most Jews in Iowa and elsewhere were drawn to Wise's plan, which advocated national religious uniformity through reform of religious

63. Israelite, 2/22/1856, 269. When Leeser established his short-lived Maimonides College in 1867, Emil Levi of Dubuque was one of the first scholars. Occident, December 1867, 42.

64. A. Rubinstein, "Isaac Mayer Wise: A New Appraisal," Jewish Social Studies 39 (1977), 68.

65. Israelite, 5/30/1856, 380. 
practices, specifically through his prayer book, Minhag America. Published in 1857 and containing Hebrew as well as German or English translations, it was to be the first step in replacing the chaotic multiplicity of minhagim and languages within and among congregations. ${ }^{66}$ Wise wrote in 1868 that he was "firmly convinced that Minhag America will create liturgical unity among American Israel." 67 Iowa congregations readily adopted the prayer book, including those in Davenport in 1862, Keokuk in 1869, and Burlington in 1875. ${ }^{68}$ In 1873 a Jew wrote from Davenport that while many in the congregation were more conservative than the Minhag America, they had agreed to use it "for the sake of peace of the congregation in this country. There is no dispute any longer how to model the service-what there was said in this or that country." 69 Many Iowa Jews, struggling to create coherent religious life, agreed with Wise that Jewish religious life should take the same, consistent form within their congregations and in others throughout the nation.

Wise advocated religious reforms, but unlike radical German reformers, who tended to think of Judaism as a universalist faith that was already suitable to all locales, he was a pragmatist who pursued reforms that he thought would better enable unification of an American Judaism. ${ }^{70}$ In 1868 he wrote to a friend, "When I claim that I know no reform congregations, Judaism and all of its congregations are for me an inseparable and untouchable whole," adding, "Judaism only has a future as a na-

66. L. J. Sussman, "Isaac Leeser and the Protestantization of American Judaism," American Jewish Archives 38 (1986), 4, http:/ /americanjewisharchives.org/publications/journal/PDF/1986_38_01_00_sussman.pdf; Temkin, Isaac Mayer Wise, 124.

67. Wise to Adolph Huebsch, 7/30/1868, Isaac Mayer Wise Digital Archive, http:/ / americanjewisharchives.org/collections/wise/home.php (accessed 1/19/2012).

68. Israelite, 7/11/1862, 10; American Israelite, 8/3/1877, 4; 10/22/1875, 2.

69. Israelite, 9/12/1873, 6.

70. On radical reform, see Rubinstein's discussion of Rabbi David Einhorn of Baltimore in "Isaac Mayer Wise," 56. See also J. J. Petuchowski, "Abraham Geiger and Samuel Holdheim: Their Differences in Germany and Repercussions in America," The Leo Baeck Institute Yearbook 22, no. 1 (1977), 139-59; and Michael A. Meyer, Response to Modernity: A History of the Reform Movement in Judaism (Detroit, 1995). 


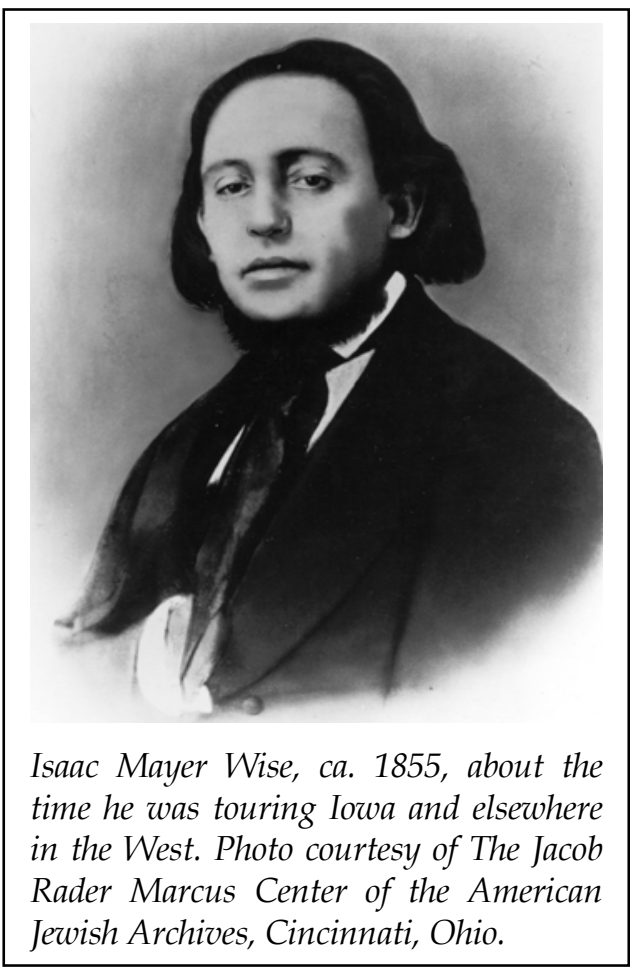

tional concept." 71 In order for Judaism to suit the American environment, where many Jews were mobile and living far from religious resources, he and others believed that it had to shed ritual and other practices that seemed not only outdated but illsuited to American life, and so reformers eliminated the second day of diasporic holiday celebration, prayer fringes, head coverings in synagogue, kosher dietary laws, exclusively Hebrew prayers, and so on. ${ }^{72}$ Moderate reformers thus created a mobile Judaism, with fewer ritual and communal forms, that could be practiced in any American locale.

71. Wise to Adolph Huebsch, 7/30/1868, Isaac Mayer Wise Digital Archive, http://americanjewisharchives.org/collections/wise/home.php (accessed 1/19/2012).

72. Lilienthal argued that the second day was not only unnecessary, but was a burden on merchants. Asmonean, 6/1/1854, 53; Bruce L. Ruben, "Max Lilienthal and Isaac M. Wise: Architects of American Reform Judaism," American Jewish Archives 55 (2003), 18, http://americanjewisharchives.org/publications/ journal/PDF/2003_55_02_00_ruben.pdf; Rubinstein, "Isaac Mayer Wise." 
There were some local tensions around reform in Iowa communities, but they were usually resolved in its favor. In 1869 a Keokuk Jew wrote, “There are some of 'Dr. Wise's men' here, as they call us, but not enough to change matters for some time to come." Later that year, however, Keokuk's congregation adopted Minhag America. By 1875 they were also using "the three year's cycle of reading the Thora [sic]" instead of the traditional annual cycle, and "the second day of every feast [was] abolished." 73 Cassi Sembach of Keokuk wrote in 1874, "Our people are fast leaving the 'shadow,' to exchange it for the 'light' of our religion." A less supportive Jew from Burlington complained that year that wealthy Jews were instituting "divine service on too much of a reform footing, for instance, worship without hats on and the reader only to read while the congregation is quiet." The next year his community wrote in to list the reforms it had embraced, including the triennial cycle, uncovered heads, and English prayers. ${ }^{74}$

Such reforms were instituted through most of the congregations in the United States, which finally united institutionally in the Union of American Hebrew Congregations (UAHC). The UAHC, first proposed in 1871 and officially founded in 1873 by lay leaders aligned with Wise, sought national cooperation and collective religious decision making, insisting that "the congregations must be united organically and systematically" in order "to preserve and elevate Judaism." 75 The UAHC built on the national connections and identifications that the press had fostered, including among Iowa Jews. Cassi Sembach, for instance, embraced these institutional plans, expressing his excitement for the day "when the union of all congregations is secured and the seminary once fairly at work." 76 When the UAHC was raising money in 1873 for a "theological institute," which was established in 1875 in Cincinnati as the Hebrew Union College, it listed men authorized to receive donations in 30 towns in Iowa,

73. Israelite, 1/15/1869, 2; American Israelite, 11/19/1875, 5. Traditionally, communities outside of the Land of Israel have observed a second day of each major holiday.

74. American Israelite, 7/10/1874, 5; 7/17/ 1874, 5; 10/22/1875, 2.

75. Israelite, 6/23/1871, 8 .

76. American Israelite, $7 / 10 / 1874,5$. 
many more than the 7 places in Minnesota and the 11 in Wisconsin, and even more than the 26 in Texas. ${ }^{77}$ Messrs. Frankel, Bach \& Co. of Oskaloosa collected money towards an indigent students fund in 1875, receiving donations from eight Jews in their own town plus an additional five Jews in Pella, Hampton, and Mason City. ${ }^{78}$ Three Vinton Jews donated to the same fund, while A. Levi of Dubuque donated to the college's "sinking fund." Congregations B'nai Israel of Keokuk and B'nai Yeshurun of Des Moines both became members of the UAHC. ${ }^{79}$

Having developed in contact with national leaders and other communities throughout the nation, Jewish communities in Iowa were quick to sign on to institutionalized versions of those connections. Notably, however, while the UAHC sometimes used state-based classifications, it was a national organization without any mediating regional or state-based structures, which meant that many concrete innovations would still require local activism. For instance, Lilienthal used the occasion of his Keokuk visit, three years after the founding of the UAHC, to make a grand statement in support of localized alliances. "In all the States of the Union, where our brethren live scattered in towns and villages, those of one county, at least, should unite" in order to support congregational life. On the national, state, and local levels, he concluded his travelogue, "In union is strength!" 80

While they continued to report on local news and fissures, most Iowa Jews agreed with Lilienthal. For several decades they had developed understandings of the relationship between their towns and larger Jewish collectives. The new institutions and religious ideologies they supported were formed in dialogue with those experiences and built on existing networks of communication and interdependence that Jews in Iowa had come to value and rely upon. Wise and other leaders wanted Judaism to flourish equally in Iowa and any other place in the United States, and so their nationalizing plans formalized the circulation of information and eased Jewish life for those with fewer resources

77. Israelite, 9/19/1873, 6 .

78. American Israelite, $12 / 10 / 1875,6$.

79. American Israelite, 3/16/1877, 6; 6/29/1877, 3.

80. American Israelite, 8/3/1877, 4. 
while rendering religious practice mobile and resolutely American. Iowa's Jewish communities were in many ways createdindividually and collectively - by their participation in the Jewish press. American Judaism as it came to be institutionally organized and ideologically conceived was also a product of the press and its negotiation of the diverse American settings-like Iowa - where Jewish life was emerging.

IN 1856 Wise reflected on his visits in Iowa and elsewhere in the West.

I am convinced that Judaism will not be forgotten in this country. Wherever the sons and daughters of Israel have made their home they remember the religion of their fathers and attempt to establish congregations.... Wherever Jewish families live, attempts are made to live according to Jewish laws and usages, and those who, by the force of circumstances, cannot do so, confess invariably, they are obliged to act contrary to their desire, and entertain the hope of being soon enabled, to live again in the pale of Israel's religion. ${ }^{81}$

Two decades later, in his Reminiscences, Wise remembered the trip differently: "I spent happy days in the Mississippi towns; the people anticipated my every wish. I saw everything, and became acquainted with every one; but withal I longed to get back into the territory of Jewish civilization." 82 Wise was both skeptical and hopeful of the prospects for Jewish life outside of major urban centers. He had created bonds with local Jews, and even though he perceived a qualitative difference between Jewish life in Iowa and in more populous Jewish locales, where it was easier to facilitate traditional observances, at the time he presented their struggles as ultimately conquerable and as intertwined with those of the nation. Jews could remain faithful and true in any place, and if Jewish life could persist in Iowa, it could persist anywhere.

The same year that Wise wrote his Reminiscences, a Jew from Burlington sought his authoritative opinion on a local matter,

81. Israelite, 8/1/1856, 29.

82. Isaac Mayer Wise, Reminiscences (Cincinnati, 1901), 297. The Reminiscences were originally published in Wise's German-language newspaper, Die Deborah, in 1874. 
because "the leading men tell me they will abide by your decision." 83 One year later a Burlington correspondent, reporting on developments in the community, wrote, "[It] is not doubtful to me that what I have to report to-day is to some degree due to the influence exercised by the American Israelite over American Israelites." 84 The Jews of Burlington, connected to Wise through his popular newspaper, saw him as both an authority and an inspiration who was deeply important to the life of their community.

These anecdotes, bookending the founding period of Judaism in Iowa and as a nationally organized entity in the United States, point to the central and interactive relationship between Jewish leaders and specific localities. Wise's ideas and institutions - but also, if less effectively, those of Leeser and otherswere formulated in dialogue with and in consideration of Jews in all kinds of places, small and large, throughout the country. At the same time, American Jews rarely lived in a bubble; they constantly interacted with Jews and Jewish leaders in other places. The American Judaism that resulted from that collaboration assumed and delighted in its national scope, while continuing to grapple with issues of unity and diversity, locality and nation, center and periphery. The geographic connections and imaginations that American Jewish publications spearheaded and facilitated created an American Jewish community that, in knowing and understanding itself, made the American continent - and many specific places within it, including Iowa-home. 85

83. American Israelite, $7 / 17 / 1874,5$.

84. American Israelite, 10/22/1875, 2.

85. Anderson, Imagined Communities; Thomas A. Tweed, Crossing and Dwelling: A Theory of Religion (Cambridge, MA, 2006). 